91. The Act as passed abolished the requirement that prospective of fice holders deny certain Catholic beliefs such as transubstantiation and the invocation of saints. The old oaths of Allegiance, Supremacy, and Abjuration, passed by Parliament under various sovereigns, from Henry VIII to William III, were eliminated. In their place, a new oath was substituted which bound members of Parliament and other office holders to serve the monarch, renounce the temporal power of the Pope in Britain, and accept the Anglican Establishment as the state church. However, priests were still excluded from Parliament, and Catholics were denied the right to serve as monarch or to hold the offices of Lord Chancellor of England, Lord Chancellor of Ireland, and Lord Lieutenant of Ireland.
92. It is interesting to note that neither the Archbishop of Canterbury nor the Archbishop of York voted.

93. Parliamentary Debates, Lords, XXI, 694-6.

94. The Bishop of Winchester, who voted for the Catholic Relief Bill, was soon to repent and rejoin their ranks.

95. Parliamentary Debates, Lords, XXI, 505-506.

96. XXVII, 702 ff; cf. Parliamentary Debates, Lords, XXV, 728-32.

97. On Mareh 5, Lord Durham showed that a petition, presented by Van Mildert, had been signed by two hundred teen age boys, ibid., XX, 720-21.

98. Stanley, Arnold, I, 226.

99. Parliamentary Debates, Lords, XX, $1329 \mathrm{ff}$., and XXI, 407-41.

100. Colchester Diary, III, 605.

\title{
1960 Brewer Prize Contest
}

The American Society of Church History announces that its next Brewer Prize competition for a book-length manuscript in church history will conclude in 1960 . The award will be announced at the annual meeting of the Society in December of this year. It will consist of a subsidy of one thousand dollars to assist the author in the publication of the winning manuscript, which shall be described on its title-page as the "Frank S. and Elizabeth D. Brewer Prize Essay of the American Society of Church History" and shall be published in a manner acceptable to the Society. If competing essays are otherwise of equal quality, preference will be given to those dealing with topics related to the history of Congregationalism. Complete manuscripts in final form, fully annotated, must be in the hands of the Secretary, Professor Winthrop S. Hudson, 1100 South Goodman St., Rochester 20, New York, by September 15, 1960. There must be two copies, a typescript and a first carbon, on standard weight paper, double-spaced, with a left-hand margin of at least an inch and one-half. 